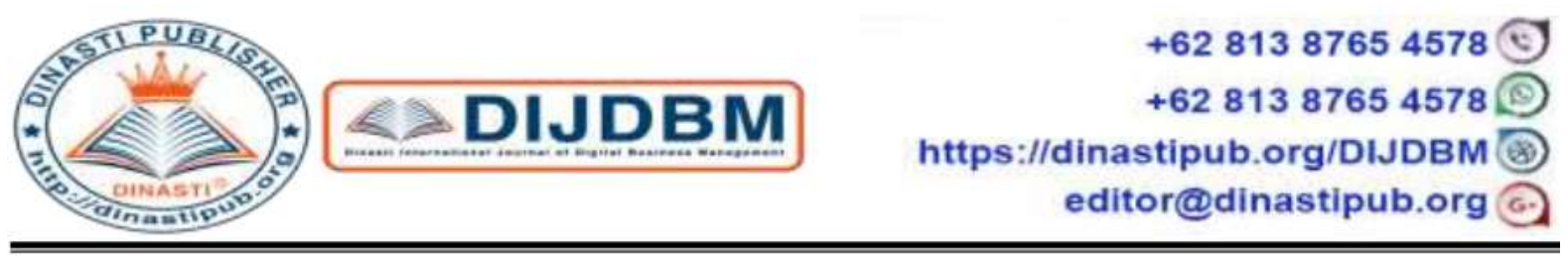

\title{
EFFECT OF SERVICE QUALITY AND RELATIONSHIP MARKETING ON CUSTOMER SATISFACTION AND ITS IMPACT ON LOYALTY SERVICE ON WISMA SOEWARNA BRACH OFFICE (KCP) OF BNI OF TANGERANG
}

Ela Ratna Yuwita ${ }^{1)}$, Arissetyanto Nugroho ${ }^{2)}$

1) Magister of Management, Lecturer of Postgraduate, Mercu Buana University, Indonesia

${ }^{2)}$ Magister of Management, Lecturer of Postgraduate, Mercu Buana University, Indonesia

\begin{tabular}{|c|l|}
\hline $\begin{array}{c}\text { ARTICLE INFORMATION } \\
\text { Received: } 30^{\text {th }} \text { January } 2020 \\
\text { Revised: } 5^{\text {th }} \text { February } 2020 \\
\text { Issued: } 9^{\text {th }} \text { February } 2020\end{array}$ & $\begin{array}{l}\text { Abstract: The purpose of this study is to determine the } \\
\text { Effect of Service Quality and Relationship Marketing } \\
\text { on Customer Satisfaction and Its Impact on Loyalty by } \\
\text { measuring indicators that affect the variable Service } \\
\text { Quality and Relationship Marketing on customer } \\
\text { satisfaction variables and their implications on } \\
\text { customer loyalty variables. This research applies a } \\
\text { descriptive research design using survey methods. } \\
\text { Ela ratna }\end{array}$ \\
$\begin{array}{l}\text { Sampling uses convinient sampling as a sampling } \\
\text { technique. This study was tested using the structural } \\
\text { equation modeling (Lisrel) approach to test the } \\
\text { significance of the significance of the overall model } \\
\text { and predetermined pathway. The findings show that } \\
\text { Service Quality and Relationship Marketing variables } \\
\text { significantly influence customer satisfaction variables. } \\
\text { Further findings indicate that Service Quality and } \\
\text { Relationship Marketing variables directly have a } \\
\text { significant effect on customer loyalty variables. This } \\
\text { study also shows that customer satisfaction has an } \\
\text { influence on customer loyalty variables. It is } \\
\text { recommended to companies to improve the excellence } \\
\text { of Service Quality and Relationship Marketing. } \\
\text { Keywords : Loyalty, Relationship Marketing, Service } \\
\text { Quality, Satisfaction, }\end{array}$ \\
\end{tabular}

\section{INTRODUCTION}

In today's business world which keeps changing, along with increasing level of competition, every company organization, whatever the form and type, and whoever the owner is will face the problem, which is how to maintain the survival of the company in the situation. Survival of the company will eventually be determined by the company's ability in getting adequate level of profitability sustainably. This includes banking companies.Bank as 
business institution is inseparable from the problem, especially related with the role of banking in economic activities as one of the machine of Indonesian development. In a dynamic economy, the existence of the banking sector has a very vital and strategic role. In this context, the main role of banking is an intermediating institution between a party with excess and a party with shortage and needs for fund to reflect the bank's health. Therefore, healthy banks will reflect healthy economy in a country, while unhealthy banks reflect poor economy of a country [14].Based on the data collected by the author, as of today, there are 134 Banks in Indonesia [2]. This increases the level of competition among the banks. Some of the well-known banks in Indonesia are below.

Table 1. List of Several Banks in Indonesia

\begin{tabular}{llll}
\hline No & BUMN Bank & $\begin{array}{l}\text { Regional Development } \\
\text { Banks }\end{array}$ & Private Bank \\
\hline 1 & Bank Mandiri & Bank DKI & Bank Central Asia \\
2 & Bank Nasional Indonesia & Bank BJB & Bank Bukopin \\
3 & Bank Rakyat Indonesia & Bank Jatim & Bank BTPN \\
4 & Bank Tabungan Negara & Bank Jateng & Bank Danamon \\
5 & & Bank Banten & Bank CIMB Niaga \\
\hline & & Bank branch offices & \\
No & Private Bank & foreign & syariah bank \\
\hline 1 & Amar Bank Indonesia & Bangkok Bank & Bank BNI Syariah \\
2 & Bank Artos Indonesia & Bank of America & Bank BRI Syariah \\
3 & Bank Bisnis Internasional & Bank of China & Bank Syariah Mandiri \\
4 & Bank Dinar Indonesia & Citibank & Bank Muamalat \\
5 & Bank Fama Internasional & Deutsche Bank & Bank Mega Syariah \\
\hline
\end{tabular}

Increasing competition and number of competitors force all banks to pay attention to the needs and wishes of the customers, and try to fulfill their expectations in more satisfying ways than other banks and their competitors.

Table 2. List of Several Banks In Indonesia

\begin{tabular}{llrrc}
\hline No & Bank & $\mathbf{2 0 1 7}$ & $\mathbf{2 0 1 8}$ & Growth \\
\hline 1 & Mandiri & 338,73 & 380,24 & 14,27 \\
2 & BRI & 328,78 & 372,13 & 13,18 \\
3 & BCA & 277,53 & 323,46 & 16,54 \\
4 & BNI & 189,35 & 224,9 & 18,77 \\
5 & CIMB & 117,82 & 131,79 & 11,77 \\
& Niaga & & & \\
6 & Danamon & 80,23 & 86,67 & 8,02 \\
7 & Panin & 75,06 & 85,67 & 12,25 \\
8 & Permata & 59,51 & 82,93 & 39,34 \\
9 & BII & 59,08 & 70,48 & 17,51 \\
10 & BTN & 47,55 & 61,99 & 30,38 \\
\hline
\end{tabular}

Table 2 shows that BNI ranks fourth in market share. This is very different from other public banks. Considering this, BNI should reform to get serious attention, otherwise BNI may be 
left behind by the competitors.Based on a survey by Marketing Research Indonesia (MRI) on service products of conventional banks, the recent low rank of BNI is caused by suboptimal services provided by BNI to the customers. In the survey, BNI is ranked fifth on the best bank service excellence. Table III. below shows the result of survey MRI survey on the bank ranking in terms of services.

Table 3. The Best Bank Service Excellence

\begin{tabular}{cl}
\hline Rank & \multicolumn{1}{c}{ Name of Bank } \\
\hline 1 & Bank Mandiri \\
2 & $\begin{array}{l}\text { Bank International Indonesia } \\
(\text { BII })\end{array}$ \\
3 & Bank OCBC NISP \\
4 & Permata Bank \\
5 & Bank Negara Indonesia (BNI) \\
6 & Bank CIMB Niaga \\
7 & Bank Rakyat Indonesia (BRI) \\
8 & Bank Central Asia (BCA) \\
\hline
\end{tabular}

Based on Table 3. BNI ranks fifth nationally in collecting public fund through bank saving products. BNI should be able to improve its quality to rank better. The services provided by BNI today are good, but BNI could be better than in 2018. In this case, the researcher performed a research on saving products in PT. Bank Negara Indonesia Tbk. The saving products to be studied were facilities offered by BNI, so any occurring problem would reduce competitiveness in maintaining customer loyalty.

The main focus of the present study was analysis of strategy programs performed by Bank Negara Indonesia in providing day-to-day services, by comparing them with the saving products of other banks.

Table 4, Customer Loyalty Index

\begin{tabular}{llrrr}
\hline No & Name Of Bank & $\mathbf{2 0 1 6}$ & $\mathbf{2 0 1 7}$ & $\mathbf{2 0 1 8}$ \\
\hline 1 & Bank Central Asia & 78 & 78,1 & 75,7 \\
2 & Bank Mandiri & 76,9 & 77,6 & 75,2 \\
3 & Bank Negara Indonesia & 75 & 77 & 74,1 \\
4 & Bank Rakyat Indonesia & 71,8 & 77,2 & 73,9 \\
5 & Bank Danamon Indonesia & 67,2 & 72,7 & 73,8 \\
6 & Bank Bukopin & 67,5 & 74,8 & 73,6 \\
7 & Panin Bank & 69,7 & 75 & 73,4 \\
8 & Bank OCBC NISP & 73,7 & 76,3 & 73,2 \\
9 & Bank UOB Buana & 74,2 & 76 & 73,1 \\
10 & Bank Internasional Indonesia & 70 & 75,5 & 73 \\
& & & & \\
\hline
\end{tabular}


Based on Table 3. and Table 4. BNI has never ranked first. BNI only ranks third. Considering Table 3. and Table 4. BNI should improve its service quality to keep their customers loyal to BNI. Equally important service is maintaining good relationship with the customers to improve customer satisfaction. This is very important because customer satisfaction is the most valuable thing for bank because it will impact customer loyalty. impact customer loyalty.

However, as banks grow and develop today, BNI Kcp Wisma Soewarna has difficulty to keep the customers loyal by maintaining long-term relationship (customer relationship) because customers are assumed to not only save their money in one bank. This is shown by the number of customers who no longer actively do transactions. It was found that among the existing customers of BNI KCP Wisma Soewarna up to 2018, only $79 \%$ were still active or often performed transactions. The remaining $21 \%$ percent was categorized as inactive in performing transactions (no longer performing transactions and very rarely performing transactions). This is shown in Table 5.

Table 5. The Number Of Clients Active And Inactive

\begin{tabular}{llllll}
\hline Year & $\begin{array}{l}\text { The } \\
\text { number of } \\
\text { clients }\end{array}$ & Active & Growth & Inactive & Growth \\
\hline 2014 & 10.338 & 8.918 & 86,26 & 1.420 & 13,74 \\
2015 & 10.738 & 9.209 & 85,76 & 1.527 & 14,22 \\
2016 & 11.480 & 9.541 & 83,11 & 1.939 & 16,89 \\
2017 & 12.644 & 10.425 & 82,45 & 2.219 & 17,55 \\
2018 & 13.050 & 10.309 & 79,00 & 2.741 & 21,00 \\
\hline
\end{tabular}

Customer loyalty is the crowning achievement of banks. Satisfied and loyal customers don't hesitate spreading news on banking products they choose. They have high credibility because they're not paid by anyone to recommend the banking product or brand. Maintaining loyal customer should be prioritized over getting new customers because recruiting new customers is difficult as if cost a lot of money. So, companies should maintain loyal customers.

The ideal situation will be realized if marketers know the needs and wishes of customers to take appropriate steps. A customer is considered loyal if they have strong commitment to buy and consume the goods regularly. Therefore, companies should know how to form customer loyalty.

\section{LITERATURE REVIEW}

Service quality is a dynamic condition related with product, service, human, process and environment which meet or exceed expectation

Relationship marketing is a marketing strategy concept which aims to form long-term relationship with customers, i.e. maintaining solid and mutually beneficial relationships between service providers and customers which could create repeat transactions and customer loyalty [12]. 
Customer satisfaction is a level in which estimated product performance is consistent with buyer's expectation. Customer satisfaction is one's happiness or satisfaction which occurs after comparing product performance or outcome with expected performance or outcome before consuming or using the product [7].

Loyalty is customer's deep commitment to return or do repeat purchase of chosen product/service consistently in the future, although situation and marketing efforts potentially cause change in behaviors.

Framework is narration (description) or statement (proposition) on identified or formulated conceptual problem solving frame. Below is the framework of the present study:

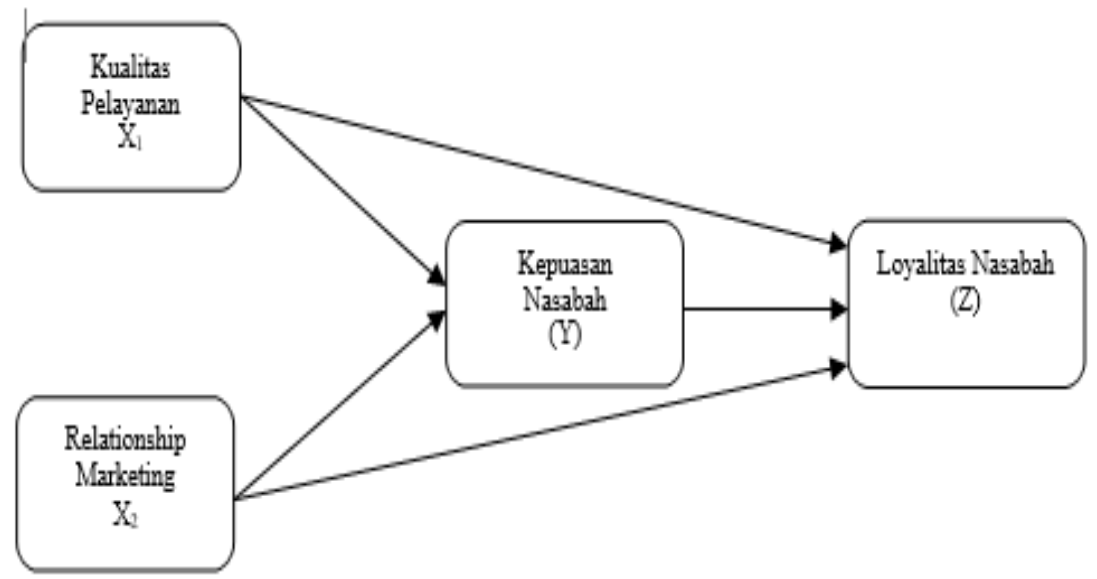

Fig. 1. Framework

\section{RESEARCH METHODS}

The present study was a causal relation using descriptive research method with survey type quantitative approach. The research population in the present study was customers of BNI KCP Wisma Soewarna of Tangerang. The research sampling used non-probability sampling with purposive sampling technique. The number of samples referred to the criteria proposed by Hair et.al [4] i.e. Maximum Likelihood Estimation (MLE) technique. The good number of samples according to MLE is 100-200 samples.

The data collection method in the present study was questionnaire using likert scale with five research scores administered to 150 respondents who met the sample criteria. The questionnaire was distributed online via google form. In the present study, the variables were categorized into: (1) Independent variables i.e.; (X1) Service quality and (X2) Relationship marketing (2) and Dependent variables i.e.; (Y1) Customer satisfaction and (Y2) Customer loyalty. The data analysis of the present study used LISREL 8.80 for processing primary data

\section{FINDINGS AND DISCUSSION}

Validity test shows how far an instrument can measure a variable to be measured. The basis for deciding whether a statement is valid or not is below: (1) if $r$ is positive and $r \geq 0.50$, then the statement item is valid, while (2) if $r$ is positive and $r<0.50$, then the statement item isn't valid. Based on Figure 3, all statement items are valid because all $r$ values of the statements are $\geq 0.50$. 


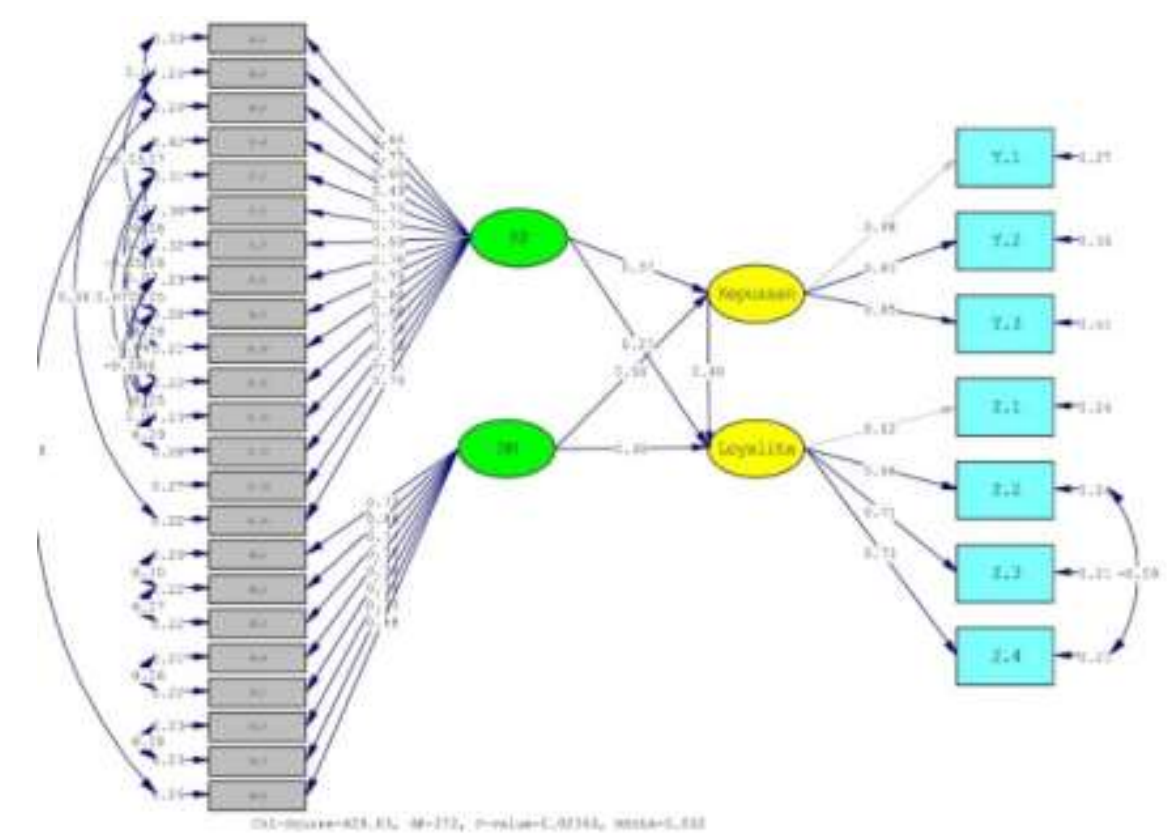

Fig. 2. Standardized Loading Factor (SLF)

Reliability test aims to determine the consistency of an instrument. The basis for deciding whether a research variable is reliable or not is as follows: (1) if Construct Reliability $\geq 0.70$ or Variance Extract $\geq 0.50$, then the research variable is reliable, while (2) if Construct Reliability $<0.70$ or Variance Extract $<0.50$, then the research variable isn't reliable. In the present study, all variables have construct reliability $\geq 0.70$ and Variance Extract $\geq 0.50$, so all research variables are reliable.

Table 6. Goodness Of Fit Index

\begin{tabular}{|c|c|c|c|c|}
\hline \multirow{2}{*}{ Goodness Of Fit } & \multicolumn{2}{|c|}{ Value of Goodness } & \multirow{2}{*}{\multicolumn{2}{|c|}{ Hasil Pengukuran }} \\
\hline & Good Fit & Marginal Fit & & \\
\hline $\begin{array}{l}\text { Normed Chi-Square } \\
\left(\chi^{2} / \mathrm{df}\right)\end{array}$ & $<2.0$ & $\begin{array}{l}2.0< \\
\mathrm{CMIN} / \mathrm{DF}< \\
3.0\end{array}$ & 1.151 & Fit \\
\hline P Value & $\begin{array}{l}0.05<\mathrm{p}< \\
1.00\end{array}$ & $\begin{array}{l}0.01<\mathrm{p}< \\
0.05\end{array}$ & 0.024 & Marginal Fit \\
\hline $\begin{array}{l}\text { Root Mean Square } \\
\text { Error (RMSEA) }\end{array}$ & $<0.08$ & & 0.032 & Fit \\
\hline $\begin{array}{l}\text { Goodness of Fit Index } \\
\text { (GFI) }\end{array}$ & $\geq 0.90$ & $0.80-<0.90$ & 0.84 & Marginal Fit \\
\hline Normal Fit Index (NFI) & $\geq 0.90$ & $0.80-<0.90$ & 0.98 & Fit \\
\hline $\begin{array}{l}\text { Non-Normed Fit Index } \\
\text { (NNFI) }\end{array}$ & $\geq 0.90$ & $0.80-<0.90$ & 1.00 & Fit \\
\hline $\begin{array}{l}\text { Comparative Fit Index } \\
(\mathrm{CFI})\end{array}$ & $\geq 0.90$ & $0.80-<0.90$ & 1.00 & Fit \\
\hline $\begin{array}{l}\text { Increamental Fit Index } \\
\text { (IFI) }\end{array}$ & $\geq 0.90$ & $0.80-<0.90$ & 1.00 & Fit \\
\hline Relative Fit Index & $\geq 0.90$ & $0.80-<0.90$ & 0.98 & Fit \\
\hline
\end{tabular}




\section{(RFI)}

Table 6 shows that model fitness value is good, i.e. good fit and marginal fit, meaning overall the fitness value of the research model shows good fit. To test research hypothesis, the significance value $(\alpha)$ is 0.005 or $5 \%$ with $t$ value of $\geq 1.96$.

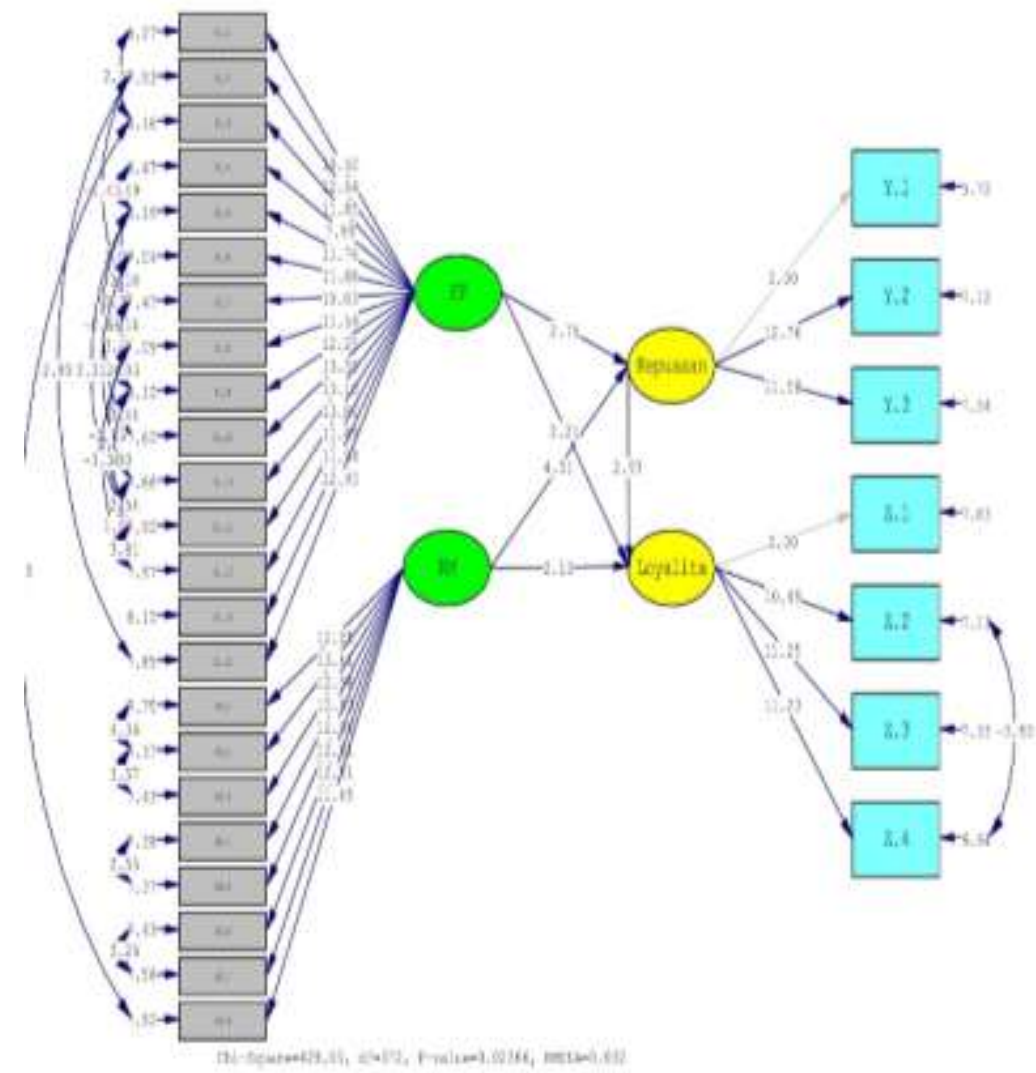

Fig. 3. T-Value

Table 7. Research Hyphotesis Result

\begin{tabular}{|c|c|c|c|}
\hline Hypothesis & Structural Path & T-Values & Conclusion \\
\hline H1 & $\begin{array}{l}\text { Service Quality-> Customer } \\
\text { Satisfaction }\end{array}$ & 2.75 & $\begin{array}{l}\text { positive and } \\
\text { significant effect }\end{array}$ \\
\hline $\mathrm{H} 2$ & $\begin{array}{l}\text { Relationship Marketing -> } \\
\text { Customer Loyality }\end{array}$ & 4.01 & $\begin{array}{l}\text { positive and } \\
\text { significant effect }\end{array}$ \\
\hline $\mathrm{H} 3$ & $\begin{array}{l}\text { Service Quality -> Customer } \\
\text { Loyality }\end{array}$ & 2.21 & $\begin{array}{l}\text { positive and } \\
\text { significant effect }\end{array}$ \\
\hline $\mathrm{H} 4$ & $\begin{array}{l}\text { Relationship Marketing -> } \\
\text { Customer Loyality }\end{array}$ & 2.13 & $\begin{array}{l}\text { positive and } \\
\text { significant effect }\end{array}$ \\
\hline H5 & $\begin{array}{l}\text { Customer Loyality -> Customer } \\
\text { Loyality }\end{array}$ & 2.93 & $\begin{array}{l}\text { positive and } \\
\text { significant effect }\end{array}$ \\
\hline
\end{tabular}


The research hypothesis (H1) states that Service Quality has direct positive and significant effect on customer satisfaction. This was shown by t-value which is 4.01 bigger than 1.96. In other words, if the service quality of BNI KCP Wisma Soewarna of Tangerang improved, it would affect customer satisfaction. Providing good service quality and security for the customers will create satisfaction for the customers and vice versa. BNI KCP Wisma Soewarna of Tangerang should reform to improve services for the customers to provide customer satisfaction so that they would use the offered services. The research result was consistent with the research result of Ilyas, A., Arshed, N., \& Hussain, T (2016) tha high quality service delivery is necessary to reach customer satisfaction. The study was in line with Lee, M.S., Hsiao, H.D., \& Yang, M.F (2011) who state that customer satisfaction is the result of service quality. Aldlaigan and Buttle in Ladhari et al. (2011) identify positive and significant correlation between service quality and overall satisfaction.

The research hypothesis (H2) states that Relationship Marketing has direct positive and significant effect on customer satisfaction. This was shown by t-value which is 4.01 bigger than 1.96. In other words, if the Relationship Marketing of BNI KCP Wisma Soewarna of Tangerang improved, it would affect customer satisfaction. It meant BNI KCP Wisma Soewarna of Tangerang should improve service quality, which was the main factor affecting customer loyalty, because customers whose personal values were satisfied and had positive mood on the services would have high loyalty to the company. The present study was in line with the studied by Sari, Y.K (2017), Putri, U.P., Suharyono. and Abdillah, Y (2014), and Synathra, V., and Sunarti (2018) wchich show that relationship marketing affects customer satisfaction. Customer satisfaction is created due to the relation formed by Bank to keep customers from moving to any other brand or company.

The research hypothesis (H3) states that Service Quality has direct positive and significant effect on customer loyalty. This was shown by t-value which is 2.21 bigger than 1.96. It meant the customers were satisfied with employees' efficiency, satisfied with employees' explanation on products, satisfied with employees who listened to their complaints. The research result was consistent with the study of Akbar and Parves (2009) which shows positive and significant relation between service quality and customer loyalty. It means good service quality will produce high customer satisfaction which could improve customer loyalty. In making policies to increase customer loyalty, service quality should be noted because it positively and significantly affects customer loyalty (Yani, 2004).

The research hypothesis (H4) states that Relationship Marketing has direct positive and significant effect on customer loyalty. This was shown by t-value which is 2.13 bigger than 1.96. The research result was consistent with the previous studies by Sari, Y.K (2017), Herdian, G and Widyastuti (2018), Putri, U.P., Suharyono., and Abdillah, Y (2014), and Synathra, V., and Sunarti (2018) which show that relationship marketing has positive and significant effect on customer loyalty.

The research hypothesis (H5) states that Satisfaction has direct positive and significant effect on customer loyalty This was shown by t-value which is 2.93 bigger than 1.96. The research result was consistent with the study by Lee, M.S., Hsiao, H.D., \& Yang, M.F (2011) which states that customer satisfaction has positive and significant effect on customer loyalty. Moreover, 


\section{CONCLUSION AND SUGGESTION}

Based on data analysis and discussion in the previous chapter, the following research conclusions are drawn:

(a) Service quality of Wisma Soewarna Brach Office (KCP) of BNI of Tangerang has positive and significant effect on customer satisfaction of Wisma Soewarna Brach Office (KCP) of BNI of Tangerang. (b) Relationship Marketing of Wisma Soewarna Brach Office (KCP) of BNI of Tangerang has positive and significant effect on customer satisfaction of Wisma Soewarna Brach Office (KCP) of BNI of Tangerang. (c) Service quality of Wisma Soewarna Brach Office (KCP) of BNI of Tangerang has positive and significant effect on customer loyalty of Wisma Soewarna Brach Office (KCP) of BNI of Tangerang. (d) Relationship Marketing of Wisma Soewarna Brach Office (KCP) of BNI of Tangerang has positive and significant effect on customer loyalty of Wisma Soewarna Brach Office (KCP) of BNI of Tangerang. (e) Customer satisfaction of Wisma Soewarna Brach Office (KCP) of BNI of Tangerang has positive and significant effect on customer loyalty of Wisma Soewarna Brach Office (KCP) of BNI of Tangerang.

By analyzing the research result, some suggestions which could be considerations and inputs for National Health Insurance (JKN) and future researchers are:

Suggestion for the company (1) Wisma Soewarna Brach Office (KCP) of BNI of Tangerang is expected to be able to grow and improve service quality as the present study found that service quality, i.e. improvement of performance, effectiveness and productivity, should be noted to provide solution for customers to allow them to get and fulfill their needs in Wisma Soewarna Brach Office (KCP) of BNI of Tangerang. It's important to note because service quality affects customer satisfaction directly and customer loyalty indirectly. (2) Wisma Soewarna Brach Office (KCP) of BNI of Tangerang is expected to be able to improve Relationship Marketing as the present study found that confidence with the indicator of good reputation has the lowest loading factor value. It shows that to improve Relationship Marketing, the company should improve the performance of employees to improve the reputation of Wisma Soewarna Brach Office (KCP) of BNI of Tangerang by resolving customer complaints correctly and swiftly. Therefore, Wisma Soewarna Brach Office (KCP) of BNI of Tangerang is expected to improve the relationship regularly and resolve customer complaint appropriately to give extra satisfaction to the customers. The strategy is expected to improve the brand's reputation and make customers trust the bank more. The reputation makes the customers more confident in the relationship between the company and the customers. Therefore, BNI is always oriented to the customers' needs, develop \& grow their confidence, create relationship with the stakeholders, be sensitive to the customers' behaviors, so BNI should be more innovative in the long term. Innovativeness isn't only about creating product or service, but also ways to maintain the customers. BNI should create good relationship with the customers by always paying attention to the, opening communication forum, reminding and inviting customers to enjoy facilities as BNI customers. (3) Wisma Soewarna Brach Office (KCP) of BNI of Tangerang is expected to be able to improve service quality and Relationship Marketing so that the customers will always perform various transactions as there is customer loyalty. Successful strategy to improve service quality and Relationship Marketing of Wisma Soewarna Brach Office (KCP) of BNI of Tangerang could create customer loyalty, so that the customers invite others to join the bank. This is very beneficial for the bank. Beside loyal customers, the bank could gain new 
customers from the exiting customers. (4) Further studies expected to do research by adding another variables affecting satisfaction and loyalty quality of service, like variable prices, service, trust, security. So it will enrich factors in question about customer satisfaction where research need much development sector, so the results can contribute positive and applicative for the world education in umumya and business development company specifically.

\section{REFERENCE}

Akbar, M.M., and Parvez, N. (2009). Impact of Services Quality, Trust, and Customer Satisfaction on Customer Loyalty, ABAC Journal, Vol. 29, No. 1, pp. 24-38.

Daftar 134 Nama Bank di Indonesia. (9 April 2018). Diterima dari https://www.zonareferensi.com/daftar-nama-bank-di-indonesia/

David L. Goetsch B Davis. 2011. Pengantar Manajemen Mutu, Ed Bahasa Indonesia. Jakarta: PT Prenhalindo.

Hair, Joseph F., William C. Black, Barry J. Babin dan Rolph E. Anderson. (2010). Multivariate Data Analysis, 7th ed. Pearson Prentice Hall. New Jersey.

Herdian, G dan Widyastuti. (2018). Pengaruh Relationship Marketing Terhadap Loyalitas Pelanggan Pada Nasabah Bank Btpn Kcp Sepanjang. Bisma (Jurnal Bisnis dan Manajemen), Volume 6,No.1.

Ilyas, A., Arshed, N., \& Hussain, T. (2016). Service Quality and Customer Satisfaction: a Study on Islamic Banks of Pakistan. Journal of Business Strategies, Vol.10, No.1.

Kotler, P. (2016). Manajamen Pemasaran, Jilid 1 dan 2. Jakarta: PT. Indeks Kelompok Gramedia.

Laporan Tahunan Bank Indonesia. (31 Mei 2019).Diterima dari: https://www.bi.go.id/id/publikasi/laporan-tahunan/bi/Default.aspx

Lee, M.S., Hsiao, H.D., \& Yang, M.F. (2011). The Study Of The Relationships Among Experiential Marketing, Service Quality, Customer Satisfaction And Customer Loyalty. International Journal of Organizational Innovation.

Oliver, R.L, 2013, "Whence Consumer Loyality”, Journal Of Marketing, Vol 63 (Special Issue), pp 33-44. Parasuraman, et al 1985

Putri, U.P., Suharyono, \& Abdillah, Y. (2014). Pengaruh Relationship Marketing Terhadap Kepuasan Dan Loyalitas Nasabah (Studi pada Nasabah Bank Jatim Cabang Pasuruan).

Saputra dan Ariningsih. (2014). Masa Depan Penerapan Strategi Relationship Marketing Pada Industri Jasa Perbankan. Jurnal Manajemen dan Bisnis, Volume 10, No. 1.

Sari, Y. (2017). Pengaruh Kualitas Pelayanan, Relationship Marketing dan Corporate Social Responsibility Terhadap Loyalitas dan Kepuasan Nasabah Bank.

[Shanmugam, Arunagiri S., Michael Thaz, Wen, Teoh Chai (2014). Factors Affecting Malaysian Behavioral Intention to Use Mobile Banking With Mediating Effects of Attitude. Academic Research International Vol. 5(2).

Synathra, V., \& Sunarti. (2018). Pengaruh Relationship Marketing Terhadap Kepuasan Nasabah Dan Dampaknya Pada Loyalitas Nasabah (Survei pada Nasabah Tabungan BCA Kantor Kas Sawojajar Kota Malang).

Yani, E. (2004). Analisis Pengaruh Kualitas Pelayanan terhadap Loyalitas Nasabah PT Bank Sumut di Medan, Tesis, Medan: Program Pascasarjana Universitas Sumatra Utara. 


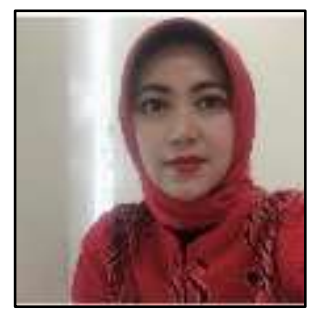

Ela Ratna Yuwita was born in Sumedang 06 June 1974. She earned her diploma(D3) (majoring accounting) 31/01/1996 from STIE INABA Bandung, and her under graduated degree (Majoring Social)from STIA Mandala Jakarta 03/07/2003 currently she is studying her Master degree in Master of Management, Mercu Buana University Jakarta Majoring in Marketing. From 1997 until present she work at PT Bank BNI Tbk as Branch Manager at Soewarna branch office Jakarta.

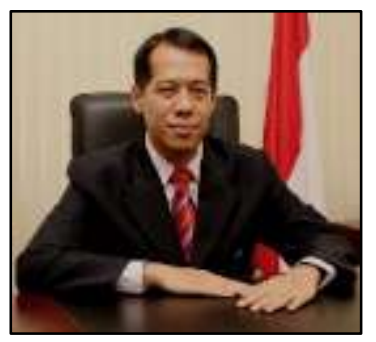

Arissetyanto Nugroho was born in Singapore, 24 ${ }^{\text {th }}$ February 1969. Graduated with a Bachelor's degree in Mechanical Engineering from the Faculty of Engineering, University of Indonesia (FTUI) and graduated as the best FTUI graduate in 1992. Continued his Masters degree in the Management Study Program of the Faculty of Economics, University of Indonesia (FEUI), graduated in 1999 and completed Doctor of Business Management IPB program in 2010. Since 2006 he joined as a lecturer at Economics and Business Faculty Mercu Buana University. Given the mandate as Vice Chancellor in 2006-2010 and as Chancellor in 20102018. He was awarded as the best performing lecturer at Mercu Buana University in 2011 and the best Entrepreneurship Lecturer in 2012. The award was also obtained both from domestic and abroad, such as 50 Faculty of Engineering Univeristy of Indonesia (FTUI) 2014 inspirational figures and Satyalencana Wira Karya 2016 honorary recipients given by the President of the Republic of Indonesia, Ir. Joko Widodo. And the best UMB Research Lecturer in 2017. Starting his career as a Sales Manager, he has been a Marketing Manager in several companies, one of them at PT Sandoz Indonesia, then became a Former Director at PT Meiji Indonesia. Currently, aside from being a permanent lecturer in the Post-graduate Program at Mercu Buana, he also runs several of his own companies engaged in the pharmaceutical field. 